\title{
Current and Future Therapeutic Targets for Pulmonary Arterial Hypertension
}

\author{
Dustin Fraidenburg ${ }^{1}$ and Jason Yuan ${ }^{2}$
}

\begin{abstract}
Fraidenburg, Dustin, Jason Yuan. Current and future targets for pulmonary arterial hypertension. High Alt Med Biol 14:134-143, 2013.-Pulmonary arterial hypertension (PAH) remains a poorly understood disorder with dire consequences. Progression of disease often leads to right heart failure and death without lung transplantation. Limited therapeutic strategies exist for the treatment of PAH and current medical treatment consists of two major categories, supportive care therapeutics and pulmonary vasculature targeted therapy. Supportive care includes anticoagulants and inotropic agents, while pulmonary vasculature targets currently available include endothelin antagonists, phosphodiesterase inhibitors and prostacyclin analogs. While these therapies have shown efficacy in hemodynamic and functional outcomes; halting the progression of disease, reversal, and clinical cure has been elusive. Combination therapy and newer agents may provide innovative insight into the disease process and ultimately change the prognosis of this fatal disease. By utilizing specific targets on the cell membrane, second messengers systems or signaling peptides, novel therapeutic strategies will hopefully emerge. In this review we discuss the currently available therapeutic options and their pulmonary vasculature targets as well as some future therapeutic targets that have promising results in human trials.
\end{abstract}

Key Words: pulmonary hypertension, nitric oxide, intracellular enzymes, ion transport, pulmonary circulation

$\mathbf{P}^{\mathrm{s}}$ ULMONARY HYPERTENSION (HTN) is the cornerstone of pulmonary vascular disease. Recognition of the mechanisms related to the development and progression of pulmonary hypertension has rapidly evolved, and identifying new therapeutic targets have changed the disease prognosis, but have failed to change the natural course of disease, a progressive decline that eventually leads to right-heart failure and death (Benza et al., 2012). Much of this research has been focused on primary pulmonary hypertension, more specifically as idiopathic pulmonary arterial hypertension (IPAH) or hereditary pulmonary arterial hypertension (HPAH). These mechanisms and therapeutic targets have also been applied to pulmonary hypertension associated with connective tissue disease, chronic liver disease, and sickle cell disease. These entities have been linked to IPAH and, under the most recent classification system, they are grouped together in WHO group 1 as pulmonary arterial hypertension (PAH), yet whether these processes are clearly synonymous remains in debate (Simonneau et al., 1009). What has remained another important question is whether much of this work can be applied to the other forms of pulmonary hypertension. Highaltitude pulmonary hypertension (HAPH), most clearly grouped with hypoxia-mediated pulmonary hypertension, shares many commonalities with $\mathrm{PAH}$, including unregulated vasoconstriction and pulmonary vascular remodeling (Heath, 1989; Heath et al, 1990). Despite these similarities, $\mathrm{PAH}$ therapy has only recently evolved into clinical trials aimed at expanding the efficacy of these medications to HAPH patients.

Treatment of PAH can be broken down into supportive care therapeutics versus pulmonary vasculature specific therapy. Vasodilators, anticoagulants, and inotropes represent treatment used for many decades, and these treatments, particularly calcium-channel blockers, have been shown to improve pulmonary outcomes dramatically, but this effect is now understood to only benefit a small subset of $\mathrm{PAH}$ patients (Sitbon et al, 2005). Therefore, newer classes of agents have been designed and, over the past 20 years, three have emerged: prostacyclin analogs, endothelin antagonists, and phosphodiesterase type 5 inhibitors (see Table 1). These agents have been shown to improve hemodynamic measurements and markers of morbidity, including quality of life and functional capacity, yet only one agent, epoprostenol, has shown a clear mortality benefit (Jing et al, 2011). Though population studies have

Departments of ${ }^{1}$ Medicine and ${ }^{2}$ Medicine and Pharmacology, University of Illinois, Chicago, Illinois. 
shown improved survival since the early 1980s, reversal or clinical cure still remains elusive (Benza et al., 2012). Newer agents in these classes with more specific targets, enhanced potency, or improved delivery are continually being developed, but it will likely take a novel agent before we can hope to improve the course of this disease.

\section{Supportive Care}

\section{Anticoagulation}

In situ thrombosis and microthrombi have been implicated in the disease pathogenesis of PAH. In one study, $38 \%$ of IPAH patients had evidence of thrombi after dissection, all with low probability V/Q scans or negative pulmonary angiograms (Pietra et al, 1989). Endothelial dysfunction, platelet activation, and abnormal plasma protein concentrations all likely contribute to the professed prothrombotic state and incidence of in situ thrombosis seen on histologic evaluation of PAH. Therefore, anticoagulation has been a mainstay of treatment and is recommended for all $\mathrm{PAH}$ patients unless contraindications exist.

Warfarin. A vitamin $\mathrm{K}$ antagonist, warfarin is the most common anticoagulant used in practice today and until recently was the only orally bioavailable anticoagulant. It is also the most commonly used anticoagulant for PAH. The evidence to support its use comes from multiple nonrandomized trials (Frank et al, 1997; Fuster et al, 1984; Rich et al, 1992). A survival benefit has been established for IPAH and because of the similarity with other forms of $\mathrm{PAH}$, the recommendation for anticoagulation extends to all WHO group 1 patients. Expert opinion dictate goals of therapy are to maintain an international normalized ratio (INR) of 1.5-2.5 in IPAH, which is slightly lower than therapeutic strategies for venous thromboembolism and CTEPH, though individual treatment strategies need to evaluate the risk/benefit ratio for anticoagulation (McLaughlin et al., 2009).

Unfractionated and low molecular weight heparins, direct thrombin antagonists, and Factor Xa inhibitors. Currently, no controlled trials exist for these other classes of anticoagulants, though case series and clinical experiences have been reported. During pregnancy, warfarin is contraindicated and can produce serious deformities in the fetus; in these instances the use of various other anticoagulants has been employed. Low molecular weight heparins have been recommended in place of warfarin during pregnancy (Huang and DeSantis, 2007). A small case series of 5 pregnant women also highlights the successful use of Factor Xa inhibtors in PAH during pregnancy (Smith et al, 2012).

Aspirin and clopidogrel. A randomized, double-blinded, placebo controlled trial evaluated the effects of aspirin (ASA) and clopidogrel on PAH patients (Robbins et al, 2006). No significant change in symptoms with either clopidogrel or ASA therapy was observed, although both decreased platelet aggregation. Kawut et al. conducted a randomized, placebocontrolled study of $92 \mathrm{PAH}$ patients to evaluate the symptomatic effects of ASA and simvastatin (Kawut et al, 2011). This study showed that $81 \mathrm{mg}$ ASA had no effect on 6-minute walk distance at 6 months. Therefore, the routine use of these medications has not been encouraged.

\section{Digoxin}

Digoxin is used as an adjunctive agent for the treatment of left ventricular systolic dysfunction and cardiac dysrhythmia. Positive inotropy, normalizing baroreceptor responsiveness, and decreasing sympathetic overdrive are all thought to improve morbidity in left ventricular dysfunction. Similar dysfunction exists in severe PAH with right ventricular failure (i.e., cor pulmonale). Rich and colleagues were the first to tackle this issue, identifying 17 patients with severe $\mathrm{PAH}$ and right heart failure, prospectively looking at the effects of digoxin (Rich et al., 1998). They identified a significant increase in cardiac output without significant changes in baroreceptor responsiveness and inconclusive data regarding sympathetic nervous system effects. There have been no large, randomized trials with digoxin, and therefore its influence on morbidity and mortality remains unknown.

\section{Dobutamine}

Dobutamine is a positive inotrope that increases myocardial contractility and reduces vascular resistance in both the pulmonary and systemic circulation (Murali et al., 1991). Dobutamine has limited effect on vasomotor tone, with weak activity on both beta-2 and alpha adrenergic receptors. Pulmonary resistance changes represent the inverse relationship of resistance and flow, as experimental animal models show no flow-independent effects of dobutamine on the pulmonary circulation (Pagnamenta et al., 2003). Increased right ventricular (RV) contractility has been confirmed in mild pulmonary hypertension (Acosta et al., 2005). It is often employed as a first-line therapy for patients with acute right heart failure. In one study of patients with PAH and acute right ventricular failure, survival was independently associated with lower requirements of dobutamine (Sztrymf et al., 2010). This agent is dispensed as a continuous intravenous infusion, therefore it remains a mainstay of inpatient treatment, but its utility in the outpatient setting is very limited.

\section{Statins}

The first observations published regarding HMG-CoA reductase inhibitors showed that simvastatin alone or in combination with calcium channel blockers or prostacyclin treatment may improve functional capacity in a small number of patients (Kao, 2005). Prospective, placebo-controlled studies of various statins has followed, but have been unable to show any significant improvement in morbidity or mortality (Barreto et al., 2008; Wilkins et al., 2010; Zeng et al., 2012). Though the data have been strong in animal models, it appears that statins alone or in combination with effective therapy for PAH has little, if any, short-term effects and longterm effects remain unknown.

\section{Targeted Therapy}

The pulmonary vasculature represents a unique environment with mechanisms that are distinctive from the systemic circulation. Therefore, cellular and molecular pathways common throughout the human body have distinct roles in the pulmonary circulation. By understanding and exploiting these pathways in the pulmonary vasculature, therapeutic approaches have been created for the treatment of PAH. Membrane receptors, second messengers, and signaling peptides all play essential roles in the 
pathogenesis of PAH and have the opportunity to become therapeutic targets.

\section{Targeting Membrane Receptors (Fig. 1)}

\section{Calcium channel blockers}

Vasodilator therapy has been used for nearly three decades to treat PAH. Calcium-channel blockers (CCBs) represent the first, well-accepted vasodilators for the treatment of $\mathrm{PAH}$, with non-dihydropyridines being the most common class, particularly nifedipine and diltiazem. In order to establish safety and efficacy with this class of medications, pulmonary vasodilatory testing has been utilized (Sitbon et al., 1998). Using a very shortacting vasodilatory agent, most commonly inhaled nitric oxide (NO), reversible vasoconstriction can be differentiated from fixed stenosis in patients with PAH. A change in mean PAP of $>10 \mathrm{mmHg}$ to an absolute $\mathrm{mPAP}<40 \mathrm{mmHg}$ without a significant decrease in cardiac output indicates a positive test (Sitbon et al., 2005). Initial studies that used slightly different criteria indicated up to $90 \%$ of patients with a positive vasoreactivity test had favorable response acutely to CCBs, where adverse reaction from CCB was seen in 38\% of nonresponders (Sitbon et al., 1998). There still remains limited utility of these medications, as recent data have shown a very small proportion of IPAH patients, $<10 \%$, will have acute vasoreactivity, and of these patients, only about half will have long-term response to calcium channel blockers (Sitbon et al., 2005).

\section{Endothelin receptor antagonists}

Endothelin (ET-1) plays a central role in the pathogenesis of $\mathrm{PAH}$ through endothelial dysfunction and vascular remodeling. Mainly synthesized in endothelial cells, but also described in vascular smooth muscle cells, ET-1 activation has its primary effect as a vasoconstrictor; it also increases VSMC proliferation and decreases apoptosis (Yanagisawa et al., 1998; Levin, 1995). Both PAH and HAPH patients have been shown to have elevated levels of circulating ET-1, which stimulates both ET-A and ET-B receptors (Giaid et al., 1993; Kojonazarov et al., 2012). ET-A receptors, located on PASMC, are thought to be the primary driver of the vasoconstrictive effect (Seo et al., 1994), while ET-B receptors are primarily located on endothelial cells and have vasodilatory effects (Hirata et al., 1993), although evidence also exists for vasoconstrictive downstream targets of ET-B, including thromboxane A2 (Dupuis et al, 1996). The above findings have led to the development of therapeutic strategies with endothelin receptor antagonists (ERA) for PAH, which has recently been expanded to the treatment of HAPH (Kojonazarov et al., 2012). The first agent, bosentan, is a dual ERA with effects on both ET-A and ET-B receptors, while newer agents are specific ET-A receptor antagonists, thought to block ET-A receptormediated vasoconstriction while maintaining the vasodilatory ET-B receptor response.

Hepatotoxicity remains the major adverse effect of the class, and though specific ET-A receptor antagonist,

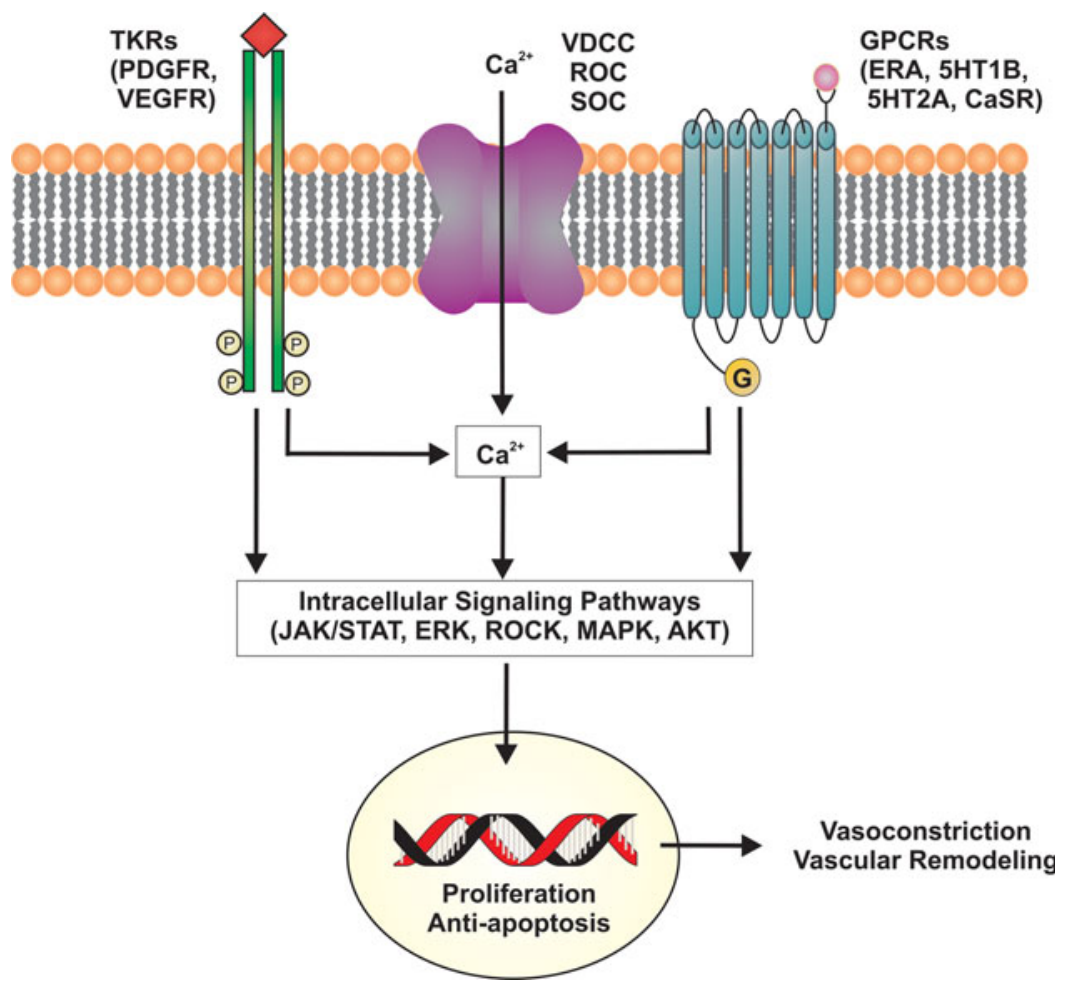

FIG. 1. Cell membrane receptors and ion channels targeted in the treatment of PAH. Ca ${ }^{2+}$, calcium; CaSR, calcium sensing receptor; ERA, endothelin receptor antagonists; ERK, extracellular signal-regulated kinase; GDP, guanosine diphosphate; GPCRs, G-protein coupled receptors; GTP, guanosine triphosphate; 5HT2A, serotonin receptor type 2A; 5HT1B, serotonin receptor type $1 \mathrm{~B}$; JAK, Janus kinase; MAPK, mitogen-activated protein kinase; PDGFR, platelet-derived growth factor receptor; ROC, receptor-operated calcium channel; ROCK, rho-associated protein kinase; SOC, store-operated calcium channel; STAT, signal transducer and activator of transcription; TKR, tyrosine kinase receptor; VDCC, voltage-gated calcium channel; VEGFR, vascular endothelial growth factor receptor. 
ambrisentan, has shown less significant elevation of liver function tests (Galie et al., 2008); a previous specific ET-A receptor antagonist was recently removed from the world market after life-threatening hepatic failure was reported, thought to be an immune or idiosyncratic reaction (Lavelle et al., 2009; Galie et al., 2011). Macitentan, a new dual endothelin receptor antagonist, is hoped to improve tissue targeting by increasing the lipophilic nature of the compound that allows once daily dosing and may also improve liver toxicity (Siharta et al., 2011). The FDA has recently announced the drug's approval, and results of a phase 3 trial are expected soon.

\section{Serotonin receptor}

Serotonin has been implicated in pulmonary hypertension pathogenesis since the first reports of stimulant medications causing PAH. Serotonin receptors, particularly $5 \mathrm{HT} 1 \mathrm{~B}$, have both direct effects on vascular contraction, as well as indirect effects on contraction and proliferation through ROS, rhoassociated protein kinase (ROCK), and extracellular signalregulated kinase (ERK) upregulation (Dempsie and McLean, 2008). The serotonin receptor has also been found to be overexpressed in IPAH patients and is thought to play a synergistic role (MacLean and Dempsie, 2010; Marcos et al., 2004). A 5HT receptor antagonist, terguride, has not shown the promising results that were hoped for in PAH treatment, though the utility of this pathway as a therapeutic target will likely continue to be important (Ghofrani et al., 2010).

\section{Tyrosine kinase inhibitors}

Imantinib was initially developed as targeted treatment for chronic myelogenous leukemia by targeting the ABL tyrosine kinase receptor, though the compound is known to have many other targets. The target that is most interesting in $\mathrm{PAH}$ is platelet-derived growth factor (PDGF) and its receptor that has been linked to vascular smooth muscle hypertrophy, possibly promoting the development of PAH (Humbert et al., 1998). Imantinib as add-on therapy for refractory PAH has shown efficacy in a recently presented oral abstract, though serious adverse reactions were more common with imantinib treatment (Hoeper et al., 2011). Whether toxicity can be mitigated with newer agents or tolerated given the severity of patients being treated remains a question that should be considered before this medication can be widely incorporated into PAH treatment regimens.

\section{Targeting Second Messengers (Fig. 2)}

\section{Phosphodiesterase inhibitors}

The cyclic guanosine monophosphate (cGMP) pathway is an important target of endothelium-derived nitric oxide, an essential vasodilatory agent (Sausbier et al., 2000). Phosphodiesterase type 5 (PDE5) rapidly hydrolyzes cGMP, inactivating its vasodilatory effects. PDE5 inhibitors have been developed that prolong the effect of cGMP by inhibiting its degradation. Sildenafil has been the first commercially available PDE5 inhibitor for the treatment of PAH. Early trials were able to show both acute hemodynamic improvements and long-term beneficial effects on hemodynamic measurements and exercise capacity (Ghofrani et al., 2002; Galie et al., 2005). Small trials have also shown sildenafil to be an effective treatment for high-altitude pulmonary hypertension, and it may also attenuate mPAP increases in normal subjects exposed to high altitude, though other trials have failed to validate this effect in normal subjects (Aldashev et al., 2005; Richalet et al., 2005; Bates et al., 2011). Oral formulation makes these agents attractive as first-line treatment of $\mathrm{PAH}$, and subsequent PDE5 inhibitors have been developed with enhanced pharmacokinetics that improve duration of action and potency (Galie et al., 2009; Rosen and Kostis, 2003; Jing et al., 2001). Adverse effects of the class are minor, with headache, edema and renal dysfunction being the most common.

\section{Soluble guanylate cyclase}

Soluble guanylate cyclase converts guanosine triphosphate (GTP) to CGMP, leading to vasorelaxation. Stimulation of soluble guanylate cyclase by a new agent, riociguat, has shown efficacy in small PAH patient populations (Grimminger et al., 2009; Ghofrani et al., 2010). Randomized, placebocontrolled trials have recently been completed, and oral abstracts have indicated positive results in both PAH and CTEPH patients, leading to an FDA drug submission for approval in the United States (Ghofrani et al., 2012a; 2012b).

\section{Rho/Rho-kinase}

The Rho/Rho-kinase pathway is an attractive target in PAH because it acts on several components in the pathogenesis of $\mathrm{PAH}$, including vasoconstriction through $\mathrm{NO}$ and calcium sensitization, vascular remodeling through cell proliferation, and inhibition of apoptosis, as well as in situ thrombosis through platelet activation (Fukumoto et al., 2007). Fasudil, a nonspecific ROCK inhibitor, has encouraging results from early human trials, particularly in high-altitude related pulmonary hypertension (Fujita et al., 2010; Kojonazarov et al., 2012).

\section{Targeting Signaling Peptides (Fig. 3) \\ Prostacyclin analogs}

Prostacyclin $\left(\mathrm{PGI}_{2}\right)$ plays an important role in vasodilation, as well as inhibition of vascular smooth muscle cell proliferation and migration. A product of the metabolism of arachidonic acid, $\mathrm{PGI}_{2}$ binds to the prostacyclin receptor (IPR) on PASMC leading to increased levels of cyclic adenosine monophosphate (cAMP), which promotes vasodilation and antiproliferative effects (Olschewski et al., 2004); as well as having effects on various other cell lines including platelet inhibition. Decreased prostacyclin release has been shown in PAH patients, which is thought to contribute to the pathogenesis of PAH (Christman et al., 1992). Epoprostenol was the first prostacyclin formulation. Initial hemodynamic studies of intravenous infusion in PAH patients showed a dosedependent decrease in PVR along with increased cardiac output (Rubin et al., 1982). This led the use of epoprostenol as a prognostic indicator of favorable response to traditional vasodilators; although, because of its short duration of action (half-life of 6 minutes) and intravenous formulation, it was not routinely used as a therapeutic agent until a decade later. At that time, continuous intravenous infusion of epoprostenol compared to traditional therapy in PAH patients showed a significant improvement in both exercise capacity and hemodynamic measurements (Barst et al., 1996). Survival in the epoprostenol group was $100 \%$ compared to $80 \%$ in the conventional therapy group over a 12 -week period, an effect not seen with previous agents and not duplicated with any other 


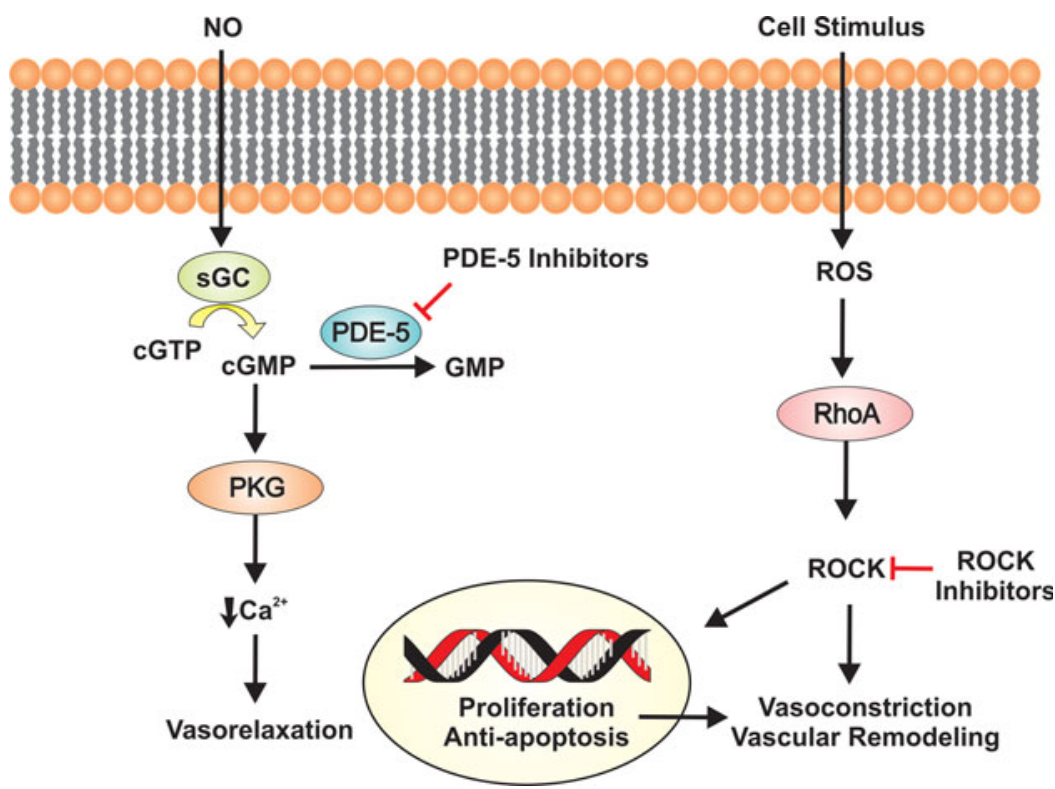

FIG. 2. Second messengers targeted in the treatment of PAH. cGMP, cyclic guanosine monophosphate; cGTP, cyclic guanosine triphosphate; GMP, guanosine monophosphate; NO, nitric oxide; PDE-5, phosphodiesterase type 5; PKG, phosphokinase G; ROCK, rho-associated protein kinase; ROS, reactive oxygen species; sGC, soluble guanylate cyclase.

currently available therapeutics. Common side effects of the class include flushing, diarrhea, HA, jaw pain, nausea, and vomiting. Intravenous epoprostenol remains a mainstay of treatment in the most severe PAH patients.

Complications of continuous intravenous administration led to development of agents with more favorable formulations. The first prostacyclin analog to be available as an inhaled formulation, iloprost was designed to target the pulmonary vasculature with minimal systemic side effects. Initial pharmacodynamics evaluation showed improvement in mean pulmonary artery pressure and cardiac output after a single dose (Olschewski et al., 1996). Long-term treatment improved exercise capacity and hemodynamic measurements which were sustained for one year (Hoeper et al., 2000). Newer delivery systems have improved the duration of action, requiring less frequent dosing (Gessler et al., 2001).

Intravenous treprostinil improved on the initial pharmacodynamics of epoprostenol by increasing the half-life, allowing time for troubleshooting in the case of pump malfunction, though significant adverse events, including bacteremia and death, still occurred (Hiremath et al, 2010). Continuous subcutaneous delivery of this medication decreased the risk of bacteremia but was associated with frequent infusion site reactions (McLaughlin et al., 2003). An inhaled formulation also is available, with improved delivery by metered dose inhaler (Voswinckel et al., 2009), and the many formulations allow more options to both care providers and patients.

Oral formulations of prostacyclin analogs have had less success than other preparations. An oral formulation of treprostinil was unable to show efficacy, though it was proposed that dose-related complications could be mitigated in future trials (Tapson et al., 2012). Beraprost was the first orally available prostacyclin analog and initial studies showed mixed results, while a long-term U.S. study was unable to show efficacy at 12 months (Barst et al., 2003). As a result of this study, beraprost has not been approved by the FDA.

Selexipag is a new agent in the prostacyclin class, though its mechanism is distinct from all previous agents. It is an orally bioavailable, selective prostacyclin receptor agonist rather than prostacyclin analog and therefore has a much lower affinity for prostaglandin receptors, which are thought to produce some of the side effects associated with this class (Morrison et al., 2010). Early data have shown improvement in pulmonary hemodynamics and a phase 3 trial is in progress (Simonneau et al., 2012).

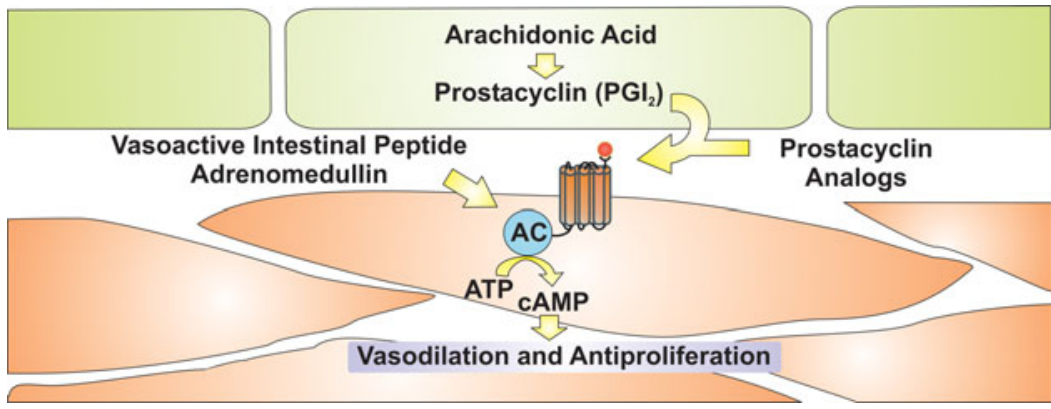

FIG. 3. Prostanoids, vasodilatory, and antiproliferative peptides for treatment of PAH. AC, adenylate cyclase; ATP, adenosine triphosphate; cAMP, cyclic adenosine monophosphate. 


\section{Vasoactive intestinal peptide}

Vasoactive intestinal peptide is a ubiquitous hormone that mediates several pathways throughout the human body; it has been linked to vasorelaxation through cAMP and cGMP pathways, which are similar to current treatment strategies of prostacyclin and PDE5 inhibitors. Aviptadil, an inhaled vasoactive intestinal peptide analog had shown early promise, yet the most recent results of a large, multicenter clinical trial has failed to show efficacy (Leuchte et al., 2008; Galie et al., 2012). Whether changes in formulation, delivery, or dose can achieve the desired effect is still to be determined.

\section{Adrenomedullin}

This circulating peptide is a potent vasodilator, with its effects mediated by cAMP and NO-dependent mechanisms (Nakamura et al., 1997). Initial human studies of both intravenous and inhaled formulations have shown evidence of efficacy in small samples, though further studies are needed to confirm this effect (Nagaya et al., 2000; 2004).

\section{Combination Therapy}

The above agents represent currently available and future therapeutic modalities, yet the best treatment approach remains unclear. It is clear that WHO functional class II patients may benefit from therapy, with a greater benefit seen in WHO functional class III. While the overall number of patients is low, patients with the most severe functional impairments fare far worse in these trials. Orally bioavailable formulations are usually employed as first-line agents because of the ease of use, either ERAs or PDE5 inhibitors. This represents a practical approach, particularly in patients with mild impairment, yet the treatment of more severe disease at presentation remains more controversial. Combination therapy with differing classes of medications, targeting multiple separate biologic pathways, becomes important as severity increases; yet at this time, with only three separate classes available, the treatment of the most severe patients usually results in utilization of all three classes. Surgical intervention or implementation of experimental agents becomes necessary if response is not optimal. Controversy arises in the patients with moderate to severe functional limitations. Single agents produce modest effects, while combination therapy may provide a synergistic effect leading to more dramatic improvement in both symptoms and hemodynamic measurements. Treatment algorithms have been proposed (Fig. 4) (McLaughlin et al., 2009; Desai and Machado, 2011), yet studies to validate these algorithms have not been undertaken. A recent abstract was presented in which a combination of epoprostenol, bosentan, and sildenafil in severe PAH patients resulted in a substantial improvement in functional and hemodynamic measurements; further studies are needed to confirm these results that may help validate the use of combination therapy (Sitbon et al., 2011).

\section{Surgical treatment}

Surgical management is infrequently required in all but the most severe PAH patients that do not respond to medical management (McLaughlin et al., 2009). Lung transplant remains the preferred surgical procedure, though significant morbidity and mortality exist, particularly in patients with poor preoperative status (Keogh et al., 2009). As of October 2010, the United Network of Organ Sharing showed IPAHlung transplant survival of $83 \%, 47.5 \%$, and $34.7 \%$ at 1,5 , and 10 years, respectively (United Network, 2012). There is still much debate whether bilateral lung transplant versus heart-lung

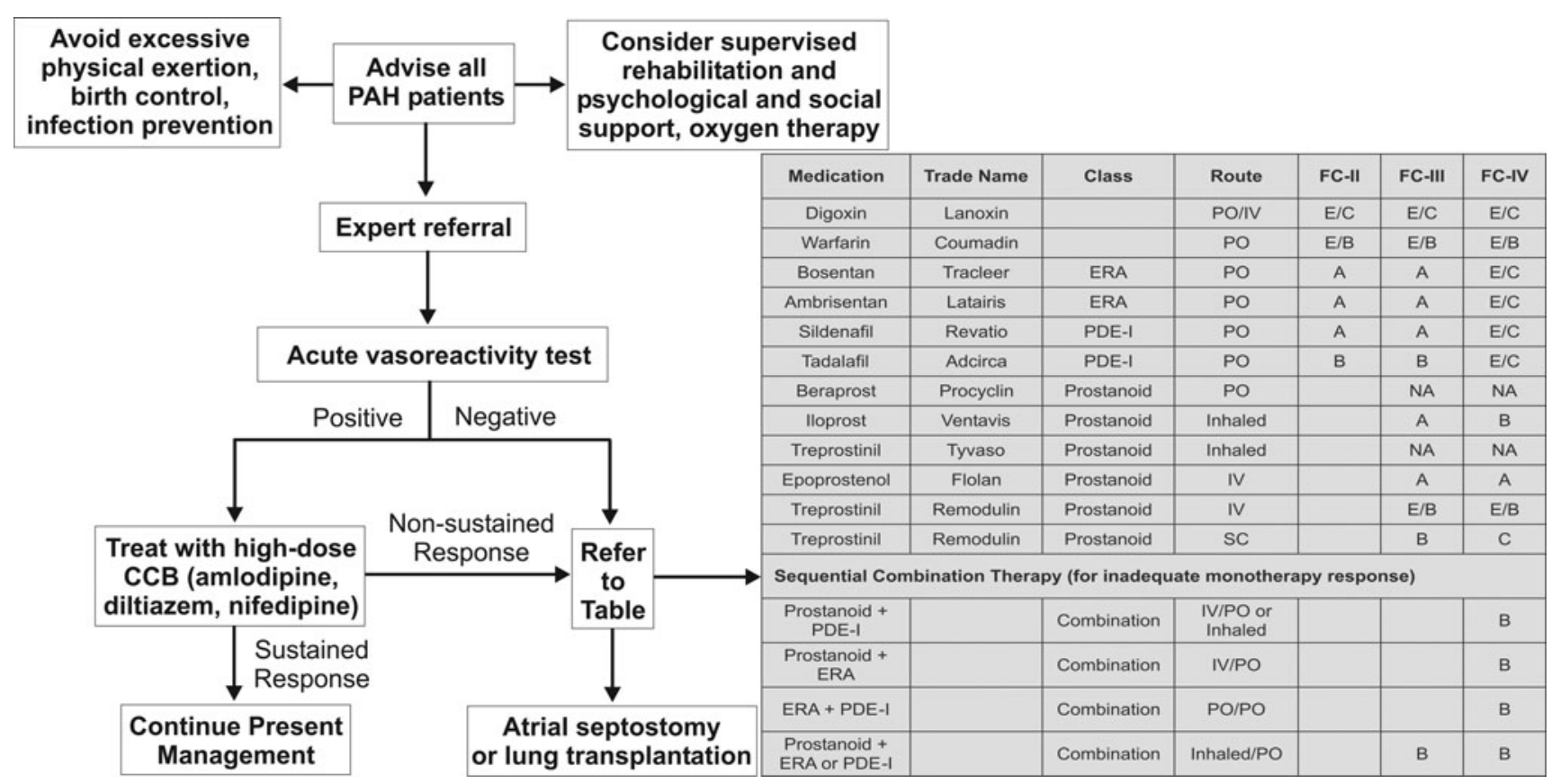

FIG. 4. PAH treatment algorithm. Proposed treatment algorithm from Desai et al, (2011). Pulmonary Circulation. ERA, endothelin receptor antagonist; FC, functional class; IV, intravenous; PDE-I, phosphodiesterase inhibitor; PO, oral.

Strength of recommendation: A-strong recommendation; B-moderate recommendation; C-weak recommendation; $\mathrm{D}$-negative recommendation; $\mathrm{E} / \mathrm{A}$ - strong recommendation based on expert opinion alone, $\mathrm{E} / \mathrm{B}$ - moderate recommendation based on expert opinion alone; $\mathrm{E} / \mathrm{C}-$ weak recommendation based on expert opinion alone; NA - not available. 
Table 1. Effects of Currently Available Therapy

\begin{tabular}{|c|c|c|c|c|}
\hline Medication & $\begin{array}{c}\text { Background therapy } \\
\text { with ET-1 antagonist, } \\
\text { PDE } 5 \text { inhibitor, } \\
\text { and/or prostacyclin } \\
\text { analog }\end{array}$ & $\begin{array}{l}\text { Functional } \\
\text { classification }\end{array}$ & $\begin{array}{l}\text { Improvement } \\
\text { in } 6 \text { minute } \\
\text { walk distance }\end{array}$ & $\begin{array}{l}\text { Change in } \\
\text { hemodynamic } \\
\text { measurements } \\
\text { at highest } \\
\text { tolerated dose }\end{array}$ \\
\hline Bosentan [Rubin et al, 2002] & None & III-IV & 36 meters@12 weeks & Not available \\
\hline Bosentan [Galie et al, 2008] & Sildenafil (15\%) & II & $\begin{array}{l}11.2 \text { meters @ } \\
24 \text { weeks (NS) }\end{array}$ & $\begin{array}{l}\mathrm{mPAP}=-2.7 \mathrm{mmHg} \\
\mathrm{PVR}=-141 \text { dynes } \\
\mathrm{CI}=0.09 \mathrm{~L} / \mathrm{min} / \mathrm{m}^{2}\end{array}$ \\
\hline $\begin{array}{l}\text { Ambrisentan [Galie et al, } \\
\text { 2008] }\end{array}$ & none & $\begin{array}{c}\text { I-IV } \\
(93 \% \text { class II-III) }\end{array}$ & 31 meters @ 12 weeks & Not available \\
\hline Sildenafil [Galie et al, 2010] & none & $\begin{array}{c}\text { II-IV } \\
(>90 \% \text { class II-III) }\end{array}$ & 50 meters@12 weeks & $\begin{array}{l}\mathrm{mPAP}=-4.7 \mathrm{mmHg} \\
\mathrm{PVR}=-261 \text { dynes } \\
\mathrm{CI}=0.37 \mathrm{~L} / \mathrm{min} / \mathrm{m}^{2}\end{array}$ \\
\hline Tadalafil [Galie et al, 2009] & Bosentan $(53 \%)$ & $\begin{array}{c}\text { I-IV } \\
(>97 \% \text { class II-III) }\end{array}$ & 33 meters @ 16 weeks & $\begin{array}{l}\mathrm{mPAP}=-4.3 \mathrm{mmHg} \\
\mathrm{PVR}=-209 \text { dynes } \\
\mathrm{CI}=0.6 \mathrm{~L} / \mathrm{min} / \mathrm{m}^{2}\end{array}$ \\
\hline Vardenafil [Jing et al, 2011] & none & II-III & 59 meters @ 12 weeks & $\begin{array}{l}\mathrm{mPAP}=-4.7 \mathrm{mmHg} \\
\mathrm{PVR}=-264 \text { dynes } \\
\mathrm{CI}=0.2 \mathrm{~L} / \mathrm{min} / \mathrm{m}^{2}\end{array}$ \\
\hline $\begin{array}{l}\text { Epoprostenol [Rubin et al, } \\
\text { 1982] }\end{array}$ & none & III-IV & 31 meters @ 12 weeks & $\begin{array}{l}\mathrm{mPAP}=-2.4 \mathrm{mmHg} \\
\mathrm{PVR}=-440 \text { dynes } \\
\mathrm{CI}=0.9 \mathrm{~L} / \mathrm{min} / \mathrm{m}^{2}\end{array}$ \\
\hline $\begin{array}{l}\text { Treprostinil (Subcutaneous) } \\
\text { [McLaughlin et al, 2003] }\end{array}$ & none & $\begin{array}{c}\text { II-IV } \\
\text { (93\% class II-III) }\end{array}$ & 10 meters @ 12 weeks & $\begin{array}{l}\mathrm{mPAP}=-2.3 \mathrm{mmHg} \\
\mathrm{PVR}=-280 \text { dynes } \\
\mathrm{CI}=0.12 \mathrm{~L} / \mathrm{min} / \mathrm{m}^{2}\end{array}$ \\
\hline $\begin{array}{l}\text { Treprostinil (Intravenous) } \\
\text { [Hiremath et al, 2010] }\end{array}$ & none & III-IV & 67 meters @ 12 weeks & Not available \\
\hline Iloprost [Hoeper et al, 2000] & none & III-IV & 75 meters@12 weeks & $\begin{array}{l}\mathrm{mPAP}=-7 \mathrm{mmHg} \\
\mathrm{PVR}=-204 \text { dynes } \\
\mathrm{CI}=0.2 \mathrm{~L} / \mathrm{min} / \mathrm{m}^{2}\end{array}$ \\
\hline $\begin{array}{l}\text { Iloprost [Olschewski et al, } \\
\text { 2002] }\end{array}$ & none & III-IV & 58.8 meters @ 12 weeks & $\begin{array}{l}\mathrm{mPAP}=-4.6 \mathrm{mmHg} \\
\mathrm{PVR}=-239 \text { dynes } \\
\mathrm{CI}=0.55 \mathrm{~L} / \mathrm{min} / \mathrm{m}^{2}\end{array}$ \\
\hline Beraprost [Barst et al, 2003] & none & II-III & $\begin{array}{l}22 \text { meters @ } 12 \text { weeks } \\
\text { (difference compared } \\
\text { to placebo) }\end{array}$ & $\begin{array}{l}\mathrm{mPAP}=+1 \mathrm{mmHg} \\
\mathrm{PVR}=+88 \text { dynes } \\
\mathrm{CI}=0.1 \mathrm{~L} / \mathrm{min} / \mathrm{m}^{2}\end{array}$ \\
\hline $\begin{array}{l}\text { Sildenafil [Simonneau et al, } \\
\text { 2008] }\end{array}$ & Epoprostenol & $\begin{array}{c}\text { I-IV } \\
\text { (71\% class II-III) }\end{array}$ & 29.8 meters @ 16 weeks & $\begin{array}{l}\mathrm{mPAP}=-2.8 \mathrm{mmHg} \\
\mathrm{PVR}=-150.6 \text { dynes } \\
\mathrm{CI}=0.9 \mathrm{~L} / \mathrm{min} / \mathrm{m}^{2}\end{array}$ \\
\hline $\begin{array}{l}\text { Bosentan [Humbert et al, } \\
\text { 2004] }\end{array}$ & Epoprostenol & III-IV & $\begin{array}{l}68 \text { meters @ } \\
16 \text { weeks (NS) }\end{array}$ & $\begin{array}{l}\mathrm{mPAP}=-6.7 \mathrm{mmHg} \\
\mathrm{PVR}=-681 \text { dynes (NS) } \\
\mathrm{CI}=0.8 \mathrm{~L} / \mathrm{min} / \mathrm{m}^{2}\end{array}$ \\
\hline $\begin{array}{l}\text { Iloprost [McLaughlin et al, } \\
\text { 2006] }\end{array}$ & Bosentan & $\begin{array}{c}\text { II-IV } \\
(94 \% \text { class III) }\end{array}$ & 30 meters @ 12 weeks & $\begin{array}{l}\mathrm{mPAP}=-6 \mathrm{mmHg} \\
\mathrm{PVR}=-164 \text { dynes } \\
\mathrm{CI}=0.1 \mathrm{~L} / \mathrm{min} / \mathrm{m}^{2}(\mathrm{NS})\end{array}$ \\
\hline $\begin{array}{l}\text { Treprostinil (Inhalation) } \\
\text { [McLaughlin et al, 2010] }\end{array}$ & $\begin{array}{l}\text { Bosentan }(70 \%) \\
\quad \text { Sildenafil }(30 \%)\end{array}$ & III-IV & 21.6 meters @ 12 weeks & Not available \\
\hline $\begin{array}{l}\text { Sildenafil [Mathai et al, } \\
\text { 2007] }\end{array}$ & Bosentan & I-IV & 46 meters @ 12 weeks & Not available \\
\hline Tadalafil [Barst et al, 2011] & Bosentan & $\begin{array}{c}\text { I-IV } \\
\text { (98\% II-III) }\end{array}$ & $\begin{array}{l}22.7 \text { meters @ } \\
16 \text { weeks (NS) }\end{array}$ & Not available \\
\hline
\end{tabular}

A summary of efficacy data available from human trials with current therapeutic agents for PAH. CI, cardiac index; mPAP, mean pulmonary arterial pressure; NS, not significant; PVR, pulmonary vascular resistance.

transplant is preferred, yet recent data suggest that outcomes are similar, although preferential heart-lung transplant is often indicated in right-heart failure (Fadel et al.). For patients in whom lung transplant is not a viable option or donor organs are unavailable, atrial septostomy may provide symptomatic improvement. Puncture of the atrial septum creates a physiological shunt through the atrial septal defect. Atrial septostomy has been shown to improve cardiac output without significant change in mean PAP and at the expense of worsening hypoxemia due to the right-to-left shunt (Law et al., 2007). The pro- 
cedure was also associated with $23 \%$ mortality, which correlated with higher presurgical right atrial pressures. Surgical management, though associated with high levels of morbidity and mortality, remains essential with insufficient medical therapies available for the most severe patients.

\section{Conclusion}

The future of PAH therapy appears promising through development of new classes of medications while improving the pharmacokinetic properties of available agents. New agents are attempting to exploit distinct pathways that may lead to more robust changes in the disease course and prognosis. These newer agents represent the future of $\mathrm{PAH}$ treatment and we remain hopeful that this debilitating, deadly disorder will soon have a more robust therapeutic arsenal in order to move toward a cure. In addition, new work focusing on the treatment of high-altitude pulmonary hypertension may be able to expand the therapeutic role of both new and established PAH treatment modalities.

\section{Author Disclosure Statement}

No competing financial interests exist.

\section{References}

Acosta F, Sansano T, Palenciano CG, et al. (2005). Effects of dobutamine on right ventricular function and pulmonary circulation in pulmonary hypertension during liver transplantation. Transplant Proc 37:3869-3870.

Aldashev AA, Kojonazarov BK, Amatov TA, et al. (2005). Phosphodiesterase type 5 and high altitude pulmonary hypertension. Thorax 60:683-687.

Barreto AC, Maeda NY, Soares RP, Cicero C, and Lopes AA. (2008). Rosuvastatin and vascular dysfunction markers in pulmonary arterial hypertension: A placebo-controlled study. Braz J Med Biol Res 41:657-663.

Barst RJ, McGoon M, McLaughlin V, et al. (2003). Beraprost therapy for pulmonary arterial hypertension. J Am Coll Cardiol 41:2119-2125.

Barst RJ, Oudiz RJ, Beardsworth A, et al. (2011). Tadalafil monotherapy and as add-on to background bosentan in patients with pulmonary arterial hypertension. J Heart Lung Transplant 30:632-643.

Barst RJ, Rubin LJ, Long WA, et al. (1996). A comparison of continuous intravenous epoprostenol (prostacyclin) with conventional therapy for primary pulmonary hypertension. $\mathrm{N}$ Engl J Med 334:296-301.

Bates MG, Thompson AA, Baillie JK, et al. (2011). Sildenafil citrate for the prevention of high altitude hypoxic pulmonary hypertension: Double blind, randomized, placebo-controlled trial. High Alt Med Biol 12:207-214.

Benza RL, Miller DP, Barst RJ, Badesch DB, Frost AE, and McGoon MD. (2012). An evaluation of long-term survival from time of diagnosis in pulmonary arterial hypertension from the REVEAL registry. Chest 142:448-456.

Christman BW, McPherson CD, Newman JH, et al. (1992). An imbalance between the excretion of thromboxane and prostacyclin metabolites in pulmonary hypertension. N Engl J Med 327:70-75.

Dempsie Y, and MacLean MR. (2008). Pulmonary hypertension: Therapeutic targets within the serotonin system. Br J Pharmacol 155:455-462.

Desai AA, and Machado RF. (2011). Diagnostic and therapeutic algorithm for pulmonary arterial hypertension. Pulm Circ 1:122-124.
Dupuis J, Goresky CA, and Fournier A. (1996). Pulmonary clearance of circulating endothelin-1 in dogs in vivo: Exclusive role of ETB receptors. J Appl Physiol 81:1510-1515.

Fadel E, Mercier O, Mussot S, et al. (2010). Long-term outcome of double-lung and heart-lung transplantation for pulmonary hypertension: A comparative retrospective study of 219 patients. Eur J Cardiothorac Surg 38:277-284.

Frank H, Mlczoch J, Huber K, Schuster E, Gurtner HP, and Kneussl M. (1997). The effect of anticoagulant therapy in primary and anorectic drug-induced pulmonary hypertension. Chest 112:714-721.

Fujita H, Fukumoto Y, Saji K, et al. (2010). Acute vasodilator effects of inhaled fasudil, a specific rho-kinase inhibitor, in patients with pulmonary arterial hypertension. Heart Vessels 25:144-149.

Fukumoto Y, Tawara S, and Shimokawa H. (2007). Recent progress in the treatment of pulmonary arterial hypertension: Expectation for rho-kinase inhibitors. Tohoku J Exp Med 211:309-320.

Fuster V, Steele PM, Edwards WD, Gersh BJ, McGoon MD, and Frye RL. (1984). Primary pulmonary hypertension: Natural history and the importance of thrombosis. Circulation 70:580587.

Galie N, Brundage BH, Ghofrani HA, et al. (2009). Tadalafil therapy for pulmonary arterial hypertension. Circulation 119:2894-2903.

Galie N, Ghofrani HA, Torbicki A, et al. (2005). Sildenafil citrate therapy for pulmonary arterial hypertension. N Engl J Med 353:2148-2157.

Galie N, Hoeper MM, Gibbs JS, and Simonneau G. (2011). Liver toxicity of sitaxentan in pulmonary arterial hypertension. Eur Respir J 37:475-476.

Galie N, Olschewski H, Oudiz RJ, et al. (2008). Ambrisentan for the treatment of pulmonary arterial hypertension: Results of the ambrisentan in pulmonary arterial hypertension, randomized, double-blind, placebo-controlled, multicenter, efficacy (ARIES) study 1 and 2. Circulation 117:3010-3019.

Galie N, Palazzini M, and Manes A. (2012). Vasoactive intestinal peptide in pulmonary arterial hypertension. Am J Respir Crit Care Med 185:7.

Galie N, Rubin L, Hoeper M, et al. (2008). Treatment of patients with mildly symptomatic pulmonary arterial hypertension with bosentan (EARLY study): A double-blind, randomised controlled trial. Lancet 371:2093-2100.

Gessler T, Schmehl T, Hoeper MM, et al. (2001). Ultrasonic versus jet nebulization of iloprost in severe pulmonary hypertension. Eur Respir J 17:14-19.

Ghofrani HA, Morrell NW, Hoeper MM, et al. (2012). Proof-ofconcept study to investigate the efficacy, hemodynamics and tolerability of terguride vs. placebo in subjects with pulmonary arterial hypertension: Results of a double blind, randomised, prospective phase IIa study. Am J Respir Crit Care Med

Ghofrani HA, Wiedemann R, Rose F, et al. (2002). Combination therapy with oral sildenafil and inhaled iloprost for severe pulmonary hypertension. Ann Intern Med 136:515-522.

Ghofrani HA, Hoeper MM, Halank M, et al. (2010). Riociguat for chronic thromboembolic pulmonary hypertension and pulmonary arterial hypertension: A phase II study. Eur Respir J 36:792-799.

Ghofrani HA, et al. (2012). Riociguat for the treatment of inoperable chronic thromboembolic pulmonary hypertension: A randomized, double-blind, placebo-controlled study (CHEST1). ACCP Atlanta, USA. Oral abstract 1462924.

Ghofrani HA, et al. (2012). Riociguat for the treatment of pulmonary arterial hypertension: A randomized, double-blind, 
placebo-controlled study (PATENT-1). CHEST 2012, Atlanta, USA. Abstract 1462799.

Giaid A, Yanagisawa M, Langleben D, et al. (1993). Expression of endothelin-1 in the lungs of patients with pulmonary hypertension. N Engl J Med 328:1732-1739.

Grimminger F, Weimann G, Frey R, et al. (2009). First acute haemodynamic study of soluble guanylate cyclase stimulator riociguat in pulmonary hypertension. Eur Respir J 33:785-792.

Heath D. (1989). Missing link from Tibet. Thorax 44:981-983.

Heath D, Williams D, Rios-Dalenz J, Calderon M, and Gosney J. (1990). Small pulmonary arterial vessels of Aymara Indians from the Bolivian andes. Histopathology 16:565-571.

Hirata Y, Emori T, Eguchi S, et al. (1993). Endothelin receptor subtype B mediates synthesis of nitric oxide by cultured bovine endothelial cells. J Clin Invest 91:1367-1373.

Hiremath J, Thanikachalam S, Parikh K, et al. (2010). Exercise improvement and plasma biomarker changes with intravenous treprostinil therapy for pulmonary arterial hypertension: A placebo-controlled trial. J Heart Lung Transplant 29:137-149.

Hoeper M, et al. Imatinib in pulmonary arterial hypertension, a randomized, efficacy study (IMPRES). Data presented at the European Respiratory Society (ERS) Annual Congress. Abstract No. 413. Presented September 25, 2011,

Hoeper MM, Schwarze M, Ehlerding S, et al. (2000). Long-term treatment of primary pulmonary hypertension with aerosolized iloprost, a prostacyclin analogue. N Engl J Med 342:1866-1870.

Huang S, and DeSantis ER. (2007). Treatment of pulmonary arterial hypertension in pregnancy. Am J Health Syst Pharm 64:1922-1926.

Humbert M, Barst RJ, Robbins IM, et al. (2004). Combination of bosentan with epoprostenol in pulmonary arterial hypertension: BREATHE-2. Eur Respir J 24:353-359.

Humbert M, Monti G, Fartoukh M, et al. (1998). Platelet-derived growth factor expression in primary pulmonary hypertension: Comparison of HIV seropositive and HIV seronegative patients. Eur Respir J 11:554-559.

Jing ZC, Yu ZX, Shen JY, et al. (2011). Vardenafil in pulmonary arterial hypertension: A randomized, double-blind, placebocontrolled study. Am J Respir Crit Care Med 183:1723-1729.

Kao PN. (2005). Simvastatin treatment of pulmonary hypertension: An observational case series. Chest 127:1446-1452.

Kawut SM, Bagiella E, Lederer DJ, et al. (2011). Randomized clinical trial of aspirin and simvastatin for pulmonary arterial hypertension: ASA-STAT. Circulation 123:2985-2993.

Keogh AM, Mayer E, Benza RL, et al. (2009). Interventional and surgical modalities of treatment in pulmonary hypertension. J Am Coll Cardiol 54(1 Suppl):S67-77.

Kojonazarov B, Isakova J, Imanov B, et al. (2012). Bosentan reduces pulmonary artery pressure in high altitude residents. High Alt Med Biol 13:217-223.

Kojonazarov B, Myrzaakhmatova A, Sooronbaev T, Ishizaki T, and Aldashev A. (2012). Effects of fasudil in patients with high-altitude pulmonary hypertension. Eur Respir J 39:496498.

Lavelle A, Sugrue R, Lawler G, et al. (2009). Sitaxentan-induced hepatic failure in two patients with pulmonary arterial hypertension. Eur Respir J 34:770-771.

Law MA, Grifka RG, Mullins CE, and Nihill MR. (2007). Atrial septostomy improves survival in select patients with pulmonary hypertension. Am Heart J 153:779-784.

Leuchte HH, Baezner C, Baumgartner RA, et al. (2008). Inhalation of vasoactive intestinal peptide in pulmonary hypertension. Eur Respir J 32:1289-1294.

Levin ER. (1995). Endothelins. N Engl J Med 333:356-363.
Maclean MR, and Dempsie Y. (2010). The serotonin hypothesis of pulmonary hypertension revisited. Adv Exp Med Biol 661:309-322.

Marcos E, Fadel E, Sanchez O, et al. (2004). Serotonin-induced smooth muscle hyperplasia in various forms of human pulmonary hypertension. Circ Res 94:1263-1270.

Mathai SC, Girgis RE, Fisher MR, et al. (2007). Addition of sildenafil to bosentan monotherapy in pulmonary arterial hypertension. Eur Respir J 29:469-475.

McLaughlin VV, Archer SL, Badesch DB, et al. (2009). ACCF/ AHA 2009 expert consensus document on pulmonary hypertension. A report of the American College of Cardiology Foundation Task Force on expert consensus documents and the American Heart Association developed in collaboration with the American College of Chest Physicians; American Thoracic Society, Inc.; and the Pulmonary Hypertension Association. J Am Coll Cardiol 53:1573-1619.

McLaughlin VV, Benza RL, Rubin LJ, et al. (2010). Addition of inhaled treprostinil to oral therapy for pulmonary arterial hypertension: A randomized controlled clinical trial. J Am Coll Cardiol 55:1915-1922.

McLaughlin VV, Gaine SP, Barst RJ, et al. (2003). Efficacy and safety of treprostinil: An epoprostenol analog for primary pulmonary hypertension. J Cardiovasc Pharmacol 41:293-299.

McLaughlin VV, Oudiz RJ, Frost A, et al. (2006). Randomized study of adding inhaled iloprost to existing bosentan in pulmonary arterial hypertension. Am J Respir Crit Care Med 174:1257-1263.

Morrison K, Ernst R, Hess P, Studer R, and Clozel M. (2010). Selexipag: A selective prostacyclin receptor agonist that does not affect rat gastric function. J Pharmacol Exp Ther 335:249255.

Murali S, Uretsky BF, Reddy PS, Tokarczyk TR, and Betschart AR. (1991). Reversibility of pulmonary hypertension in congestive heart failure patients evaluated for cardiac transplantation: Comparative effects of various pharmacologic agents. Am Heart J 122:1375-1381.

Nagaya N, Kyotani S, Uematsu M, et al. (2004). Effects of adrenomedullin inhalation on hemodynamics and exercise capacity in patients with idiopathic pulmonary arterial hypertension. Circulation 109:351-356.

Nagaya N, Nishikimi T, Uematsu M, et al. (2000). Haemodynamic and hormonal effects of adrenomedullin in patients with pulmonary hypertension. Heart 84:653-658.

Nakamura M, Yoshida H, Makita S, Arakawa N, Niinuma H, and Hiramori K. (1997). Potent and long-lasting vasodilatory effects of adrenomedullin in humans. Comparisons between normal subjects and patients with chronic heart failure. Circulation 95:1214-1221.

Olschewski H, Rose F, Schermuly R, et al. (2004). Prostacyclin and its analogues in the treatment of pulmonary hypertension. Pharmacol Ther 102:139-153.

Olschewski H, Simonneau G, Galie N, et al. (2002). Inhaled iloprost for severe pulmonary hypertension. $N$ Engl J Med 347:322-329.

Olschewski H, Walmrath D, Schermuly R, Ghofrani A, Grimminger F, and Seeger W. (1996). Aerosolized prostacyclin and iloprost in severe pulmonary hypertension. Ann Intern Med 124:820-824.

Pagnamenta A, Fesler P, Vandinivit A, Brimioulle S, and Naeije R. (2003). Pulmonary vascular effects of dobutamine in experimental pulmonary hypertension. Crit Care Med 31:1140-1146.

Pietra GG, Edwards WD, Kay JM, et al. (1989). Histopathology of primary pulmonary hypertension. A qualitative and quantitative study of pulmonary blood vessels from 58 
patients in the National Heart, Lung, and Blood Institute, primary pulmonary hypertension registry. Circulation 80: $1198-1206$.

Rich S, Kaufmann E, and Levy PS. (1992). The effect of high doses of calcium-channel blockers on survival in primary pulmonary hypertension. N Engl J Med 327:76-81.

Rich S, Seidlitz M, Dodin E, et al. (1998). The short-term effects of digoxin in patients with right ventricular dysfunction from pulmonary hypertension. Chest 114:787-792.

Richalet JP, Gratadour P, Robach P, et al. (2005). Sildenafil inhibits altitude-induced hypoxemia and pulmonary hypertension. Am J Respir Crit Care Med 171:275-281.

Robbins IM, Kawut SM, Yung D, et al. (2006). A study of aspirin and clopidogrel in idiopathic pulmonary arterial hypertension. Eur Respir J 27:578-584.

Rosen RC, and Kostis JB. (2003). Overview of phosphodiesterase 5 inhibition in erectile dysfunction. Am J Cardiol 92:9M-18M.

Rubin LJ, Badesch DB, Barst RJ, et al. (2002). Bosentan therapy for pulmonary arterial hypertension. N Engl J Med 346:896-903.

Rubin LJ, Groves BM, Reeves JT, Frosolono M, Handel F, and Cato AE. (1982). Prostacyclin-induced acute pulmonary vasodilation in primary pulmonary hypertension. Circulation 66:334-338.

Sausbier M, Schubert R, Voigt V, et al. (2000). Mechanisms of NO/cGMP-dependent vasorelaxation. Circ Res 87:825-830.

Seo B, Oemar BS, Siebenmann R, von Segesser L, and Luscher TF. (1994). Both ETA and ETB receptors mediate contraction to endothelin-1 in human blood vessels. Circulation 89:1203-1208.

Sidharta PN, van Giersbergen PL, Halabi A, and Dingemanse J. (2011). Macitentan: Entry-into-humans study with a new endothelin receptor antagonist. Eur J Clin Pharmacol 67:977-984.

Simonneau G, Robbins IM, Beghetti M, et al. (2009). Updated clinical classification of pulmonary hypertension. J Am Coll Cardiol 54:S43-54.

Simonneau G, Rubin LJ, Galie N, et al. (2008). Addition of sildenafil to long-term intravenous epoprostenol therapy in patients with pulmonary arterial hypertension: A randomized trial. Ann Intern Med 149:521-530.

Simonneau G, Torbicki A, Hoeper MM, et al. (2012). Selexipag: An oral, selective prostacyclin receptor agonist for the treatment of pulmonary arterial hypertension. Eur Respir J 40:874-880.

Sitbon O, Humbert M, Jagot JL, et al. (1998). Inhaled nitric oxide as a screening agent for safely identifying responders to oral calcium-channel blockers in primary pulmonary hypertension. Eur Respir J 12:265-270.
Sitbon O, Humbert M, Jais X, et al. (2005). Long-term response to calcium channel blockers in idiopathic pulmonary arterial hypertension. Circulation 111:3105-3111.

Sitbon O, Jais X, Savale L, et al. (2011). Upfront triple combination therapy of i.v. epoprostenol with oral bosentan and sildenafil in idiopathic and heritable pulmonary arterial hypertension. Am J Respir Crit Care Med 183:A5910.

Smith JS, Mueller J, and Daniels CJ. (2012). Pulmonary arterial hypertension in the setting of pregnancy: A case series and standard treatment approach. Lung 190:155-160.

Sztrymf B, Souza R, Bertoletti L, et al. (2010). Prognostic factors of acute heart failure in patients with pulmonary arterial hypertension. Eur Respir J 35:1286-1293.

Tapson VF, Torres F, Kermeen F, et al. (2012). Oral treprostinil for the treatment of pulmonary arterial hypertension in patients on background endothelin receptor antagonist and/or phosphodiesterase type 5 inhibitor therapy (the FREEDOM-C study): A randomized controlled trial. Chest 142:1383-1390.

United Network for Organ Sharing. Available at: http:// www.unos.org; Accessed December 10, 2012.

Voswinckel R, Reichenberger F, Gall H, et al. (2009). Metered dose inhaler delivery of treprostinil for the treatment of pulmonary hypertension. Pulm Pharmacol Ther 22:50-56.

Wilkins MR, Ali O, Bradlow W, et al. (2010). Simvastatin as a treatment for pulmonary hypertension trial (SiPHT). Am J Respir Crit Care Med 181:1106-1113.

Yanagisawa M, Kurihara H, Kimura S, et al. (1988). A novel potent vasoconstrictor peptide produced by vascular endothelial cells. Nature 332:411-415.

Zeng WJ, Xiong CM, Zhao L, et al. (2012). Atorvastatin in pulmonary arterial hypertension (APATH) study. Eur Respir J 40:67-74.

Address correspondence to: Dustin Fraidenburg, M.D. Department of Medicine University of Illinois 909 South Wolcott Avenue Chicago 60612, Illinois

E-mail: dfraiden@uic.edu

Received January 11, 2013; accepted in final form February 5, 2013 